\title{
Reciproc Blue $x$ V-File: a study on the performance of two reciprocant instruments after third use
}

Reciproc Blue x V-Fille: un estudo sobre o desempenho de dois instrumentos reciprocantes após terceiro uso

Reciproc Blue x V-File: un estudio sobre el rendimiento de dos instrumentos alternativos después del tercer uso

\author{
Anna Elisa Souza Simião \\ ORCID: https://orcid.org/0000-0003-1925-293X \\ Faculdade de Ilhéus, Brazil \\ E-mail: elisaanna337@gmail.com \\ Maria Clara Santos Silva \\ ORCID: https://orcid.org/0000-0003-4851-437X \\ Faculdade de Ilhéus, Brazil \\ E-mail: clara.maria.23@hotmail.com \\ Edeilton Santana de Oliveira Júnior e Bezerra \\ ORCID: https://orcid.org/0000-0001-6766-8855 \\ Faculdade de Ilhéus, Brazil \\ E-mail:edeiltonjunior@hotmail.com \\ Caio Cesar Souza \\ ORCID: https://orcid.org/0000-0002-6445-5157 \\ ENDOBAHIA Cursos, Brazil \\ E-mail: caioitaobim@hotmail.com \\ Adolfo de Matos de Carvalho \\ ORCID: https://orcid.org/0000-0002-4421-660X \\ Faculdade de Ilhéus, Brazil \\ E-mail: adolfodecarvalho@outlook.com \\ Ana Grasiela da Silva Limoeiro \\ ORCID: https://orcid.org/0000-0003-4633-720X \\ Faculdade de Ilhéus, Brazil \\ Email: grasielalimoeiro@gmail.com
}

\begin{abstract}
Objective: The cleaning and shaping of root canals is undeniably a step of great importance for the success of endodontic treatment. With the aim of optimizing the time and quality of this step, numerous instruments of different materials and shapes have been developed over the years. One of these instruments was nickel-titanium files, which have greater flexibility and resistance, allowing a better prognosis for endodontic treatment. In this study, two endodontic files, Reciproc Blue and V-File, were compared with the aim of evaluating their performance after the third use. Materials and methods: 60 acrylic blocks wrapped with laminated paper and filled with Nankin ink were used. Instrumentation was performed with an endodontic engine, by an experienced operator. After instrumentation, the blocks were photographed so that the photographs were superimposed. Results: After statistical analysis, it was found that there was no significant difference in the performance of the two groups after the third use. Conclusion: There was no significant difference between the two studied groups, and both are safe for the preparation of curved canals, but it is necessary that the manufacturer's recommendation is followed, regarding the number of canals instrumented with the same file. Keywords: Instrumentation; Endodontic files; Root canals; Reciprocating instruments; Reciproc Blue; V-file.
\end{abstract}

\section{Resumo}

Objetivo: A limpeza e modelagem dos canais radiculares é, sem dúvida, uma etapa de grande importância para o sucesso do tratamento endodôntico. Com o objetivo de otimizar o tempo e a qualidade dessa etapa, inúmeros instrumentos de diferentes materiais e formas foram desenvolvidos ao longo dos anos. Um desses instrumentos foram as limas de níqueltitânio, que apresentam maior flexibilidade e resistência, permitindo melhor prognóstico para o tratamento endodôntico. Neste estudo, duas limas endodônticas, Reciproc Blue e V-File, foram comparadas com o objetivo de avaliar seu desempenho após o terceiro uso. Materiais e métodos: foram utilizados 60 blocos de acrílico envoltos em papel laminado e preenchidos com tinta Nankin. A instrumentação foi realizada com motor endodôntico, por operador experiente. Após a instrumentação, os blocos foram fotografados para que as fotos fossem sobrepostas. Resultados: Após análise estatística, constatou-se que não houve diferença significativa no desempenho dos dois grupos após o terceiro uso. 
Conclusão: Não houve diferença significativa entre os dois grupos estudados e ambos são seguros para o preparo de canais curvos, porém é necessario que a recomendação do fabricante seja seguida, no que diz respeito a quantidade de canais intrumentados com uma mesma lima.

Palavras-chave: Instrumentação; Instrumentos endodônticos; Canal radicular; Instrumentos reciprocantes; Reciproc Blue; V-file.

\begin{abstract}
Resumen
Objetivo: La limpieza y el modelado de los conductos radiculares es, sin duda, un paso muy importante para el éxito del tratamiento endodóntico. Con el fin de optimizar el tiempo y la calidad de esta etapa, se han desarrollado numerosos instrumentos de diferentes materiales y formas a lo largo de los años. Uno de estos instrumentos fueron las limas de níquel-titanio, que tienen mayor flexibilidad y resistencia, lo que permite un mejor pronóstico del tratamiento endodóntico. En este estudio se compararon dos limas de endodoncia, Reciproc Blue y V-File, con el objetivo de evaluar su rendimiento tras el tercer uso. Materiales y métodos: Se utilizaron 60 bloques acrílicos envueltos en papel laminado y rellenos con tinta Nankin. La instrumentación se realizó con un motor de endodoncia, por un operador experimentado. Después de la instrumentación, se fotografiaron los bloques para que las fotos pudieran superponerse. Resultados: Después del análisis estadístico, se encontró que no hubo diferencia significativa en el desempeño de los dos grupos después del tercer uso. Conclusión: No hubo diferencia significativa entre los dos grupos estudiados y ambos son seguros para la preparación de canales curvos, pero es necesario que se siga la recomendación del fabricante, en cuanto al número de canales instrumentados con la misma lima.
\end{abstract}

Palabras clave: Instrumentación; Limas de endodoncia; Canales raíz; Instrumentos alternativos; Reciproc Blue; V file.

\title{
1. Introduction
}

Cleaning and shaping of the root canal is one of the most important phases of endodontic treatment, and filling should not be neglected. Proper cleaning and shaping facilitates disinfection and three-dimensional filling of the root canal system (Schilder, 1974).

Instrumentation is a fundamental step for the success of endodontic treatment. For this success to be significant, the quality of the modeling procedure must be present and there must be no procedural errors such as instrument deviations and fractures that can affect the prognosis (Fernandes et al., 2020). One of the goals of cleaning and shaping the root canal is to minimize the number of bacteria and their byproducts and to allow efficient sealing of the canal system, thus eliminating infection and healing apical periodontitis (Pereira et al. 2013).

To accelerate the root canal modeling phase and reduce the working time, the use of reciprocal nickel-titanium (NiTi) instruments has been proposed. These instruments represent a major advance for endodontics, as they are more flexible and resistant, and also effectively reduce microorganisms when used in conjunction with the irrigation solution. The main advantages of using rotary instruments in the preparation of root canals are the reduced time required for preparation and the ability to easily follow the curvature of the canal due to the greater flexibility of NiTi files, maintaining their original shape with less material being extruded through the apical path (Cerqueira et al., 2007).

Reciprocal motion consists of counterclockwise (cutting direction) and clockwise (instrument release) rotations. The angle of the cutting direction is greater in the counterclockwise direction than in the clockwise direction, therefore the instrument moves continuously towards the apex of the root canal. With this technique, only one reciprocal instrument can be used to prepare the root canal, which makes endodontic treatment more economical, eliminates the possibility of cross-contamination, and increases the fatigue resistance of the instruments (Yared, 2008).

Reciproc Blue (VDW, Munich, Germany) is the second generation of Reciproc instruments, in which an innovative heat treatment has been applied that consists of heatingand cooling the instrument to regulate phase transition temperatures, change the molecular structure of Turns On, and give the instrument a blue color. This thermomechanical treatment was reported to improve the overall performance of the instrument compared to the previous generation, showing greater flexibility, higher fatigue strength with a significant increase in mean fracture time, and lower surface microhardness, which may indicate that this 
proprietary thermomechanical treatment produces a NiTi alloy that is softer and more ductile than the conventional one. (Keskin et al., 2018; De-deus et al., 2017)

V File (TDK, Curitiba, Brazil) is a heat-treated instrument that has higher flexibility and resistance. It has a regressive taper to avoid unnecessary wear of the tooth's coronal wall and is suitable for curved and atresic canals. (Available at: www.novaendovita.com).

The aim of this study was to compare the cutting capacity and strength of Reciproc Blue and V File, two reciprocal NiTi instruments, after the third use. Since endodontic treatment may involve potential complications related to the complex anatomy of root canals and the need for satisfactory cleaning and shaping, the lack of effective endodontic instruments may lead to accidents during treatment. The null hypothesis tested is that there is no significant difference between the groups.

\section{Metodology}

Sixty acrylic blocks (IM do Brasil, São Paulo, Brazil) were divided into 3 groups of reciprocal files $(n=20)$. The RECB group represented the Reciproc Blue system (VDW, Munich, Germany) and the VF group (TDK, Curitiba, Brazil) represented the V-File system. The groups were further divided into 3 subgroups $(n=10)$ representing the cycle with which the instruments were used and autoclaved.

The blocks were filled with black Nankin ink (Acrilex, China), photographed to record the original shape of the canals and compared with the images after instrumentation, then wrapped with laminated paper to avoid affecting the instrumentation, and then positioned in a lathe (TORNIN, Belo Horizonte, Brazil) with the curvature to the left.

Prior to first use, the V-file instruments were autoclaved at $126 \mathrm{C}, 30$ psi for 26 minutes. Reciproc Blue instruments are factory autoclaved as single use is recommended. The RECB1 and VF1 subgroups represent new RECB and VF instruments. All instruments were autoclaved after each use and used for the second (RECB2 and VF2) and third time (RECB3 and VF3) according to the manufacturer's recommendations.

During instrumentation, all simulated root canals were prepared by the same experienced operator as indicated by the manufacturer. All canals were prepared using an IRoot Pro endodontic device (Bassi/ Easy Equipamentos Odontológico, Belo Horizonte, Brazil) with the following rotation angles: $170^{\circ}-50^{\circ}$ degrees. Before root canal preparation, the patency of the root canal was checked with a \#10 K file (Dentsply Maillefer, Ballaigues, Switzerland).

The working length was set at $17 \mathrm{~mm}$ (total block length). Each file was used with 3 pecking movements and then removed from the canal and cleaned with gauze. After the three movements, the instrument was removed, and the canals were rinsed with $5 \mathrm{~mL}$ of distilled water in a hypodermic syringe and an Endo-Eze needle (Ultradent Products, Utah, USA) until no debris remained in the blocks. Instrumentation was considered complete when the working length was reached.

After final instrumentation of the RECB3 and VF3 subgroups, the plastic blocks were placed in the previously determined position and a digital photograph of each instrumented block was taken after instrumentation. The corresponding images before and after instrumentation were overlaid using Adobe Photoshop CS5.1 (Adobe Systems, San Jose, USA). The contours of the canals were traced using custom experimental software that measured the distances between unprepared and prepared canals (Figure 1). 
Figure 1 - Images before and after instrumentation, superimposed with measurement points (a) canal opening, (b) midway between the canal opening and the beginning of the curve, (c) beginning of the curve, (d) apex of the curve, and (e) foramen.

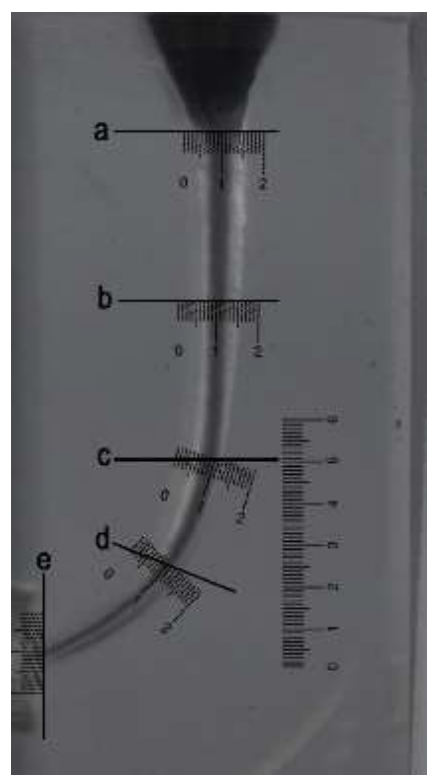

Source: Silva et al. 2021.

\subsection{Evaluation of canal preparation:}

Five points were assigned to different planes of each canal image. In the canal mouth (A), midway between the canal mouth and the beginning of the curve (B), the beginning of the curve (C), the apex of the curve (D), and the end point of the simulated canal (E). The 5 points were used as a reference to compare the images before and after instrumentation (Keskin et al., 2018).

The pre-instrumentation and post-instrumentation images were processed using Adobe Photoshop CS5.1 such that the post-instrumentation image was superimposed on the pre-instrumentation image to facilitate assessment of channel centering/transport. The distance between the plotted center before instrumentation and the center after instrumentation was measured and recorded for each of the 5 reference points; this measurement determined the transport distance.

To measure the centering ability of the canal, the transport distance at each point was determined by plotting the measurements from the center of the canal before instrumentation to the points after instrumentation, where $\mathrm{X} 1$ is the maximum extent of movement of the instrument in one direction (inside of the curvature), X2 is the movement of the instrument in the opposite direction, and $\mathrm{Y}$ is the total diameter of the canal preparation. Once these data were collected, they were inserted into the formula Total: X1-X2/Y (Lim et al., 2013). (figure 2) 
Figure 2 - X1 represents the maximum amount of movement from the canal to the inside of the curve and X2 represents movement in the opposite direction. $\mathrm{Y}$ is the diameter of the final canal preparation.

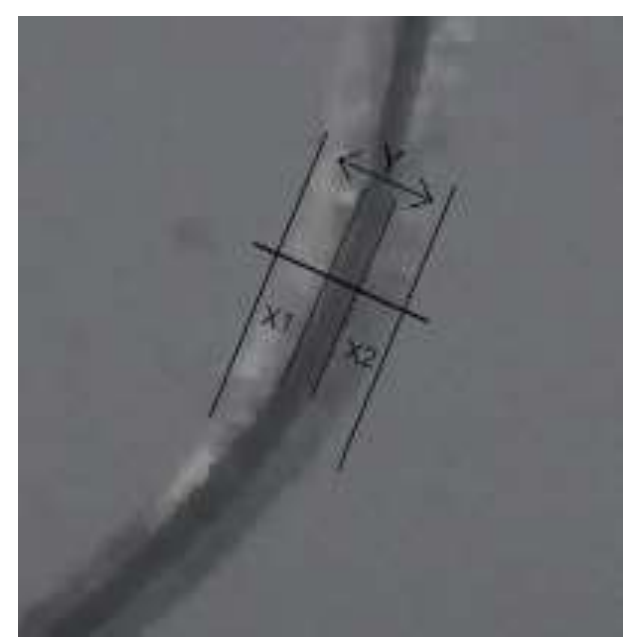

Source: Authors.

\subsection{Statistical analysis:}

The Shapiro-Wilk test was used, the purpose of which is to check whether the data have a normal distribution-like distribution $(\mathrm{p}>0.05)$ or not $(\mathrm{p}<0.05)$. In this case, it is checked whether the variables are normally distributed.

If the data are normally distributed, the T-test for independent samples was used, if they are not normally distributed, the Mann Whitney test was used. If $\mathrm{p}<0.05$, there are significant differences; if $\mathrm{p}>0.05$, there are no significant differences.

\section{Results}

During the third use, one instrument broke from the Reciproc Blue group and a step formed in 3 blocks of the same group (Figure 3).

Figure 3 - Presence of a step between points (d) curve vertex and (e) foramen.

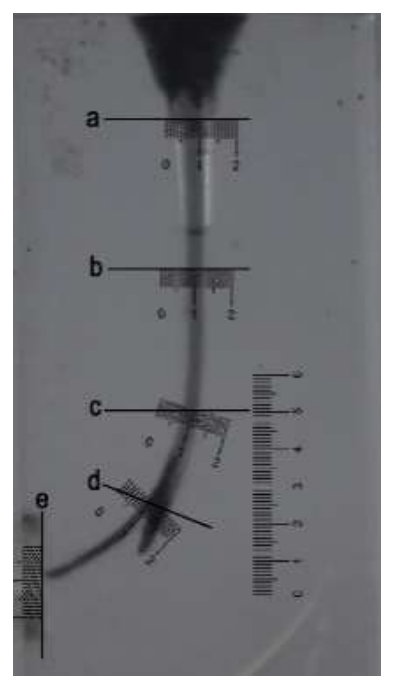

Source: Authors. 
Table 1 shows the width of the simulated canals at 5 different points after instrumentation and irrigation with the V-File and Reciproc Blue endodontic files. The results in Table 1 show that there was no significant difference between the V-File and Reciproc Blue groups at the third application.

Table 1 - Canal transport distance $(\mathrm{mm})$ at 5 different measurement points after canal preparation with 2 instruments.

\begin{tabular}{lccc}
\hline Measuring points & Reciproc Blue & V-File & p- value \\
\hline (a) Canal oriffice & $1,25 \pm 0,18$ & $1,28 \pm 0,11$ & $>0,659$ \\
\hline $\begin{array}{l}\text { (b) Midway between the canal mouth and the beginning of } \\
\text { the curve }\end{array}$ & $1,02 \pm 0,19$ & $1,03 \pm 0,05$ & \\
\hline (c) The beginning of the curve & $0,86 \pm 0,16$ & $0,89 \pm 0,07$ & $>0,608$ \\
\hline (d) The apex of the curve & $0,8 \pm 0,19$ & $0,78 \pm 0,08$ & $>0,728$ \\
\hline (e) The end point of the simulated canal & $0,54 \pm 0,21$ & $0,62 \pm 0,19$ & $>0,376$ \\
\hline
\end{tabular}

Values are presented as means \pm standard deviations. Source: Authors.

Table 2 shows the mean amount of resin removed at the five points of the canal with the V-File and Reciproc Blue instruments.

Table 2 - mean values of the inner and outer width $(\mathrm{mm})$ of the canals at 5 different measuring points after preparation of the canal with 2 instruments.

\begin{tabular}{|c|c|c|c|c|c|c|c|c|c|c|}
\hline & \multicolumn{2}{|c|}{ (a) Canal oriffice } & \multicolumn{2}{|c|}{$\begin{array}{l}\text { (b) Midway between the } \\
\text { canal mouth and the } \\
\text { beginning of the curve }\end{array}$} & \multicolumn{2}{|c|}{$\begin{array}{l}\text { (c) The beginning of the } \\
\text { curve }\end{array}$} & \multicolumn{2}{|c|}{ (d) The apex of the curve } & \multicolumn{2}{|c|}{$\begin{array}{l}\text { (e) The end point of the } \\
\text { simulated canal }\end{array}$} \\
\hline & Inner & Outer & Inner & Outer & Inner & Outer & Inner & Outer & Inner & Outer \\
\hline VF & $0,27 \pm 0,07$ & $0,44 \pm 0,13$ & $0,22 \pm 0,06$ & $0,39 \pm 0,11$ & $0,29 \pm 0,9$ & $0,2 \pm 0,09$ & $0,18 \pm 0,12$ & $0,25 \pm 0,07$ & $0,11 \pm 0,14$ & $0,19 \pm 0,17$ \\
\hline \multicolumn{11}{|c|}{$\begin{array}{l}\text { Values are given as means } \pm \text { standard deviations. Different superscripts indicate a difference, indicate a statistically significant difference between } \\
\text { groups }(\mathrm{p}<0.05) . \mathrm{RB}-\text { Reciproc Blue. VF }-\mathrm{V} \text {-file. Source: Authors. }\end{array}$} \\
\hline \multirow{2}{*}{\multicolumn{11}{|c|}{$\begin{array}{l}\text { In both the V-File and Reciproc Blue groups, more resin was removed from the outside of the curve than from the } \\
\text { de. This was true for all points of the canal except the area at the beginning of the curve, but there was no significant difference } \\
\text { veen the V-File and Reciproc Blue files on the inside and outside of the curve. }\end{array}$}} \\
\hline & & & & & & & & & & \\
\hline \multicolumn{5}{|c|}{ Measuring points } & \multicolumn{2}{|c|}{ Reciproc Blue } & \multicolumn{2}{|c|}{ V-file } & \multicolumn{2}{|c|}{ p-value } \\
\hline \multicolumn{5}{|c|}{ (a) Canal oriffice } & \multicolumn{2}{|c|}{$-0,04 \pm 0,12$} & \multicolumn{2}{|c|}{$-0,05 \pm 0,11$} & \multicolumn{2}{|c|}{$>0,741$} \\
\hline \multicolumn{5}{|c|}{$\begin{array}{l}\text { (b) Midway between the canal mouth and the beginning } \\
\text { of the curve }\end{array}$} & \multicolumn{2}{|c|}{$-0,15 \pm 0,15$} & \multicolumn{2}{|c|}{$-0,16 \pm 0,15$} & \multicolumn{2}{|c|}{$>0,873$} \\
\hline \multicolumn{5}{|c|}{ (c) The beginning of the curve } & \multicolumn{2}{|c|}{$0,03 \pm 0,09$} & \multicolumn{2}{|c|}{$0,07 \pm 0,16$} & \multicolumn{2}{|c|}{$>0,503$} \\
\hline \multicolumn{5}{|c|}{ (d) The apex of the curve } & \multicolumn{2}{|c|}{$-0,16 \pm 0,13$} & \multicolumn{2}{|c|}{$-0,14 \pm 0,19$} & \multicolumn{2}{|c|}{$>0,781$} \\
\hline \multicolumn{5}{|c|}{ (e) The end point of the simulated canal } & \multicolumn{2}{|c|}{$-0,18 \pm 0,22$} & \multicolumn{2}{|c|}{$-0,17 \pm 0,24$} & \multicolumn{2}{|c|}{$>0,843$} \\
\hline
\end{tabular}

Values are given as means \pm standard deviations. Source: Authors.

\section{Discussion}

The phase of instrumentation and irrigation of the root canal is of great importance for the success of endodontic treatment. For this purpose, a flexible instrument with cutting capacity, a suitable technique, an experienced professional and the use of an auxiliary chemical substance are essential. (Medeiros et al., 2011). NiTi files have changed reprocessing techniques, 
as their handling can be subjected to a thermomechanical process that gives them greater instrumentation safety and flexibility (Piazza et al., 2021). The aim of this study is to evaluate the formability and cleaning efficiency of two different groups of single files, Reciproc Blue 25.08 and V-File 25.08. Single-rooted acrylic blocks were used for standardization to minimize variables and ensure a more accurate result. (Topçuoğlu; Topçuoğlu, 2017).

Reciproc Blue R25 exhibited significantly higher cyclic fatigue resistance than Wave One Gold Primary and Reciproc R25 (Keskin et al., 2017). This result is believed to be due to the blue heat treatment, as the physical properties and modes of operation of the three instruments are identical. Reciproc R25 showed better flexural strength and a significant increase in mean fracture time compared to Reciproc despite similar roughness patterns (De deus et al., 2016), in addition to higher torsional strength (Almeida et al., 2019). However, Reciproc Blue files require less torque to experience the same angular deflection, which means they have lower torsional strength until fracture. When the elastic limit of the file is exceeded by the torsional stress, it deforms plastically and this is an important parameter to analyze when it comes to instrumentation safety, because if this stress is maintained, it will cause the file to break (Farias et al., 2021). Among the Reciproc Blue, ProDesign R and Wave One Gold instruments, Reciproc Blue showed greater torsional strength than the other instruments tested and showed significantly greater angular rotation (Silva et al., 2018).

RB showed greater widening at the canal hole, midway between the hole and the beginning of the curve, at the beginning of the curve, and at the apex of the curve, while WOG showed greater widening only at the end point of the canal (Keskin et al., 2018). In this study, the two file groups had very similar preparations and did not show wide preparations at any of the points examined.

Regarding the centering ability of the canal, the RBlue files had greater transport to the outside of the curve at points (a) the canal opening, (b) on the path between the canal opening and the beginning of the curve, and (d) the apex of the curve, while the VF files had greater outward transport at points (a) mouth of the canal, (b) on the path between the mouth of the canal and the beginning of the curve, (d) apex of the curve, and (e) foramen; at point (c) beginning of the curve, the preparation was centered.

All canals were prepared in a reciprocal motion. This motion was designed primarily to reduce torsional stress around the instrument, which reduces the risk of fracture compared with rotational motion. (Keskin et al., 2017). Reciproc Blue exhibits lower resistance to cyclic fatigue in canals with a curvature of $90^{\circ}$ than artificial canals that have a curvature of $45^{\circ}$ (Oezyuerek et al., 2018). The artificial canals used in this study had a curvature of $45^{\circ}$.

The present study was the first to compare Reciproc Blue and V-File files. On the other hand, the performance and resistance of Reciproc Blue files have already been extensively tested in published studies. The results have shown that the VFile files have an excellent performance and are safer in the third use, as they did not suffer fractures and did not cause steps compared to Reciproc Blue, although without significant differences.

Finally, despite some different characteristics in terms of torsional strength, there were no significant differences between the two groups tested, so the null hypothesis was accepted.

\section{Conclusion}

There was no significant difference between the two tested groups, and both are safe for the preparation of curved canals, but it is necessary to follow the manufacturer's recommendations regarding the number of canals instrumented with the same file. 
Research, Society and Development, v. 10, n. 15, e174101522849, 2021

(CC BY 4.0) | ISSN 2525-3409 | DOI: http://dx.doi.org/10.33448/rsd-v10i15.22849

\section{References}

Almeida, G. C., Guimarães, L. C., Resende, P. D., Buono, V. T. L., Peixoto, I. F. C., \& Viana, A. C. D. (2019). Torsional behaviour of Reciproc and Reciproc blue instruments associated with their martensitic transformation temperatures. International endodontic journal, 52(12), 1768-1772.

Cerqueira, L. G., Gomes, C. C., Penina, P., Prado, M. A., Freitas, L. F., Camões, I. C. G., \& Fidel, R. (2007). Técnicas de instrumentação manual e rotatória: comparação da modelagem dos canais radiculares. Revista Brasileira de Pesquisa em Saúde/Brazilian Journal of Health Research.

De-Deus, G., Silva, E. J. N. L., Vieira, V. T. L., Belladonna, F. G., Elias, C. N., Plotino, G., \& Grande, N. M. (2017). Blue thermomechanical treatment optimizes fatigue resistance and flexibility of the Reciproc files. Journal of endodontics, 43(3), 462-466.

Fernandes, C., Cardoso, R., Hilgenberg, S. P., Frozoni, M., Mendez, E. C., Braitt, A. H., ... \& da Silva Limoeiro, A. G. (2020). Análise comparativa da qualidade da instrumentação de limas manuais em canais simulados: K-flexofile e ProDesign M. Brazilian Journal of Health Review, 3(6), $18854-18863$.

Farias, A. L. V. (2020). Eficácia das limas reciprocantes Reciproc Blue e Prodesign R na remoção de material obturador: uma revisão integrativa da literatura. Keskin, C., Demiral, M., \& Sariyllmaz, E. (2018). Comparison of the shaping ability of novel thermally treated reciprocating instruments. Restorative dentistry \& endodontics, 43(2).

Keskin, C., Inan, U., Demiral, M., \& Keleş, A. (2017). Cyclic fatigue resistance of Reciproc Blue, Reciproc, and WaveOne Gold reciprocating instruments. Journal of endodontics, 43(8), 1360-1363.

Lim, Y. J., Park, S. J., Kim, H. C., \& Min, K. S. (2013). Comparison of the centering ability of Wave. One and Reciproc nickel-titanium instruments in simulated curved canals. Restorative dentistry \& endodontics, 38(1), 21-25.

Medeiros, J. M. F., Haddad Filho, M. S., Habitante, S. M., da Rosa, L. C. L., Salum, G., \& Almeida, E. T. D. C. (2017). Perda de corte da lima protaper quanto a esterilização e número de uso. Revista de Odontologia da Universidade Cidade de São Paulo, 23(3), 228-237.

Özyürek, T., Gündoğar, M., Uslu, G., Yılmaz, K., Staffoli, S., Grande, N. M., ... \& Polimeni, A. (2018). Cyclic fatigue resistances of Hyflex EDM, WaveOne gold, Reciproc blue and 2shape NiTi rotary files in different artificial canals. Odontology, 106(4), 408-413.

Pereira, H. S. C., da Silva, E. J. N. L., \& de Souza Coutinho-Filho, T. (2013). Movimento reciprocante em Endodontia: revisão de literatura. Revista Brasileira de Odontologia, 69(2), 246.

Piazza, G. C., do Amaral Capello, P., Almeida, C. N., Blatt, J. A., \& Ferreira, R. (2021). Avaliação do número de canais modelados com limas ProDesign M até sua fratura, simulados em blocos de resina acrílica. Orbis Science, 1(1), 46-56.

Silva, E. J. N. L., Vieira, V. T. L., Hecksher, F., dos Santos Oliveira, M. R. S., dos Santos Antunes, H., \& Moreira, E. J. L. (2018). Cyclic fatigue using severely curved canals and torsional resistance of thermally treated reciprocating instruments. Clinical oral investigations, 22(7), 2633-2638.

Silva, M. R., de Carvalho, A. D. M., Rodrigues, M. A., Souza, C. C., Rosas, C. A. P., Cardoso, R. M., \& da Silva Limoeiro, A. G. (2021). Estudo In Vitro da limpeza de canais simulados (Wave One Gold x W-File). Research, Society and Development, 10 (13), e541101321693-e541101321693.

Silva, M.C.S., Simião, A.E.S., Souza C.C., Rodrigues, M.A., Oliveira Junior,E.S., Carvalho,A.M., Limoeiro.A.G. (2021). Avaliação da capacidade de modelagem de dois sistemas reciprocantes: Reciproc Blue x V-File. Research, Society and Development, 10 (15), e177101522870.

Schilder, H. (1974). Cleaning and shaping the root canal. Dent Clin North Am, 18, 269-296.

Topçuoğlu, H. S., \& Topçuoğlu, G. (2017). Cyclic fatigue resistance of Reciproc Blue and Reciproc files in an S-shaped canal. Journal of endodontics, 43(10), $1679-1682$.

Yared, G. (2008). Canal preparation using only one Ni-Ti rotary instrument: preliminary observations. International endodontic journal, 41(4), 339-344. 